\title{
The Slaying of Sir William Pennington: Legal Narrative and the Late Medieval English Archive
}

\section{Shannon McSheffrey}

On 20 April 1532, near the king's palace at Westminster, two gentlemen, Richard Southwell, esquire, and Sir William Pennington, faced one another in a sword fight, a quarrel that ended in Pennington's death. The slaying came at a sensitive time in Henry VIII's reign, when much attention was focused on 'the King's Great Matter,' his divorce of Katherine of Aragon and projected marriage to Anne Boleyn. The killing of William Pennington was bound up in those issues, one version of events depicting the genesis of the quarrel in an alleged disparagement of Anne Boleyn's virtue. ${ }^{1}$ The official version, however, recorded on the rolls of the Court of King's Bench, told a different story, one that omitted the larger political issues that underlay the quarrel between these two men, giving us important indications about how legal records were composed and used in premodern England to manage politically sensitive issues. ${ }^{2}$ The records of this affair reveal the use of both formal and informal channels, from local juries to the king's council, for dealing with acts of violence in Henrician England,

1 The case has received minimal scholarly attention as in itself it represents no more than a footnote in the larger political story of the early 1530 s. It has been briefly, and deftly, treated in passing by historians Steven Gunn and Stanford Lehmberg; Gunn, Charles Brandon, 125; and Lehmberg, "Southwell, Sir Richard (1502/3-1564)." For a general discussion of the political climate at Henry's court in 1532, see Bernard, The King's Reformation, 50-68; more generally on the Crown and the judiciary, see Williams, The Tudor Regime, 375-405.

2 More generally for the 'management of image' in Tudor England, see Sharpe, Selling the Tudor Monarchy. 
particularly those with serious political repercussions. These official and unofficial processes, and the records they generated, ${ }^{3}$ were tightly imbricated; although in a legal sense the plea roll at King's Bench was more or less sufficient unto itself, politically its record worked only in tandem with the unofficial negotiations and manoeuvres behind the scenes. In turn, the political imperatives demanded that the formal processes be massaged, that the official record read in particular ways and not others regarding the facts of the case - which were probably not the 'facts' at all.

Narratives told in legal records - whether premodern or modern - are not just stories, but stories purported to be true, in a context (a court of law) where 'truth' had a very high value. This assuredly does not mean, however, that the narratives written in legal documents are mimetic records of 'what really happened.' Legal narratives are always constructed and shaped, because accounts have to fit into particular formulae which legal documents require and because, in general, creating a narrative is an interpretive act that confers meaning on, and provides a rationale for, the way in which events follow from one another. ${ }^{4}$ Legal narratives are sometimes also more deliberately crafted, because parties to the legal process sometimes embellish or lie outright in establishing their accounts. Such fictions are tremendously interesting as historical evidence, although distinguishing the lies from the reliable statements (leaving aside for the moment what 'reliable' might mean) is often impossible, especially for more distant historical periods. Occasionally - as in the Pennington killing - alternative narratives survive, which allow us to glimpse, if only imperfectly, the complicated processes that lay behind the establishment of a fictive version written onto the plea roll.

Stories recorded in legal submissions and records had much in common with those written in other more conventionally literary contexts, but the instrumentality of their purpose was much more prominent. A legal narrative recorded in a document was written to achieve a particular legal outcome - and the narrative was constructed in particular ways to accomplish that purpose. ${ }^{5}$ The main narrative in

3 My approach here is influenced by scholarship taking the 'archival turn'; see, for instance, Davis, Fiction in the Archives; Farge, Le goût de l'archive; Steedman, Dust; and the essays in Burton, ed., Archive Stories; and in Blouin and Rosenberg, eds., Archives.

4 On narratives in legal documents, see Davis, "Les conteurs de Montaillou," 69-71; Gewirtz, "Narrative and Rhetoric in the Law"; Brooks, "Narrative Transactions"; Gaskill, Crime and Mentalities, 24-29; Gowing, "The Haunting of Susan Lay"; and Walker, Crime, Gender and Social Order, 5-8.

5 Gewirtz, "Narrative and Rhetoric in the Law," 5-7. 
this case, the indictment of Richard Southwell and his retinue for the slaying of Sir William Pennington, can be analysed along several axes. As a legal submission, the narrative had to conform to the requirements of its genre ${ }^{6}$ (although, as explored below, in some circumstances it could take liberties with or ignore conventions). As an intervention in a fraught political situation, the narrative had to steer in certain directions and avoid others. As a purportedly 'true' account, it had to seem faithful to what people believed had happened, or at least had to seem close enough to pass. Understanding how this legal narrative worked involves considering all these issues - legal forms and expectations, the particular political moment, what was thought to have happened to William Pennington on 20 April 1532. The meaning of the legal narratives was derived both from the words on the documents themselves and from their contexts, because the words and expressions used in the text were connected to and gained meaning from actions, processes, projections, and assumptions the writer and reader brought to it. They thus cannot be understood without reference to the world that lay outside the text.

If to most historians the desirability of examining the embeddedness of texts in contexts seems obvious ${ }^{7}$ and, indeed, the very stuff of historical scholarship, investigating the text/context relationship leads to epistemologically difficult terrain. Deconstruction of a text (in this case the indictment) demonstrates that the remains of the past are far from straightforwardly mimetic, and yet establishing a 'context' to understand why the text was structured in the way it was depends on treating evidence (generally derived from texts) as revelatory of the situations that produced them. ${ }^{8}$ I cannot here pretend to solve that epistemological dilemma and will treat the evidence using the usual exegetical techniques to try to understand how the fragments relate to one another. ${ }^{9}$ The analysis below presents what seems to me, having examined the evidence from as many angles as possible, the most likely scenario, a scenario developed from close analyses of the documents as well as inferences about what lies between and behind the texts.

6 On the form of indictments, see Baker, Oxford History, 6:523-25.

7 It is of course not incontrovertible to all scholars, most influentially Jacques Derrida ("Il n'y a pas de hors-texte"); Derrida, De la grammatologie, 227, or, in English translation, Of Grammatology, 158.

8 See Spiegel's very useful discussion of these issues in The Past as Text, esp. xvii-xxi, 14-27, 44-56; and Stein, "Literary Criticism and the Evidence for History," 78-79.

9 See Partner, "Making Up Lost Time," 110. 


\section{The King's Bench Narrative}

The story told in the report of the coroner's inquest jury, later deposited in the Court of King's Bench and serving as an indictment for the killing, needs first to be laid out. ${ }^{10}$ What follows is a close paraphrase of the Latin indictment (transcribed and translated in the Appendix below).

On 20 April 1532, the king's coroner for the abbot of Westminster's liberty convened an inquest over the body of Sir William Pennington, who lay dead inside the Westminster sanctuary. Sixteen jurors reported that earlier that same day Richard Southwell, esquire, late of London, was walking back and forth inside Westminster Hall (where the courts of Common Pleas and King's Bench sat) ${ }^{11}$ talking to John Peryent, esquire, about settling a suit that Sir William Pennington had launched against Southwell. In the midst of their discussion, Pennington himself barged in and accused Southwell of saying something to John Grey that made Pennington appear a liar. ${ }^{12}$ Southwell replied that he had said no such thing, but if he were to call Pennington a liar, he would easily be able to prove it with good witnesses. At this, Pennington's face became flushed, and with great malice he swore by God's blood and cried (the following words recorded in the vernacular), "Yf thow wyll abyde by the wordes I shall kytt [cut] thy knaves flesshe!" Richard Southwell rejoined, "Yf thow kytt my flesshe, I shall kytt thy flesshe ageyn lyke a knave!" Pennington then called Southwell outside, challenging him to meet at Tothill Street in the town of Westminster, or else he, Pennington, would tell everyone he met that Southwell was the "sterkest coward knave on lyve [alive]." Pennington and Southwell each left Westminster Hall and gathered their retinues; Southwell's included his two brothers, Robert and Anthony, and four other men. The two parties met on a bridge at the end of the causeway that spanned the ditch separating the monastic precinct of Westminster Abbey from Tothill Street. Members of each retinue tried to dissuade the two men from violence. One of Pennington's servants, seeing his malice and rage, pleaded with him not to

10 The coroner's inquest was filed among the indictments for the Trinity term of 1532 and then copied into the Coram Rege rolls for Easter 1533. TNA, KB 9/520, m. 12; KB 27/1087, rex m. 8 (see Appendix). The Coram Rege rolls (KB 27), along with the King's Bench Controlment Rolls (KB 29) and the rolls of the Court of Common Pleas (CP 40), cited below, are available online at the Anglo-American Legal Tradition website at <http://aalt.law.uh.edu>, managed by Robert Palmer.

11 The courts had begun the 1532 Easter law term on 17 April.

12 This sentence is unclear in the original (see Appendix), although the general point about lying is clear. 
engage: "Sir, there be many more then we be, therfore a nother day schalbe better then nowe." Pennington replied, "If thow be a ferd [afraid] go thy wey orellis do as thy harte serveth the for my wey lyeth thys wey," and he continued to move towards Southwell. John Peryent, the erstwhile mediator, again tried to defuse their quarrel, running after Richard Southwell, taking him by the elbow and saying to him, "Richard Southwell, for the passion of Cryste, be content. What wyll yow doo wyll yow undo yowre self and all yowres?" Southwell answered, "Sir wyll ye hold me tyll I be slayne? I pray yow suffer me to be at large and stay Penyngton, [if] yow shall ordre me." A swordfight ensued, with Southwell striking Pennington a serious blow, and Pennington returning the hits, until Pennington had Southwell on the ground ready to thrust his sword into him. Anthony Southwell, seeing his brother in peril of death, then and there feloniously struck William Pennington on the left side of his head, with a sword worth four shillings. ${ }^{13}$ This blow gave Pennington a mortal wound from which he immediately died. Thus, Anthony Southwell, on the day and year and at the place and time specified above, on the aforesaid causeway, feloniously slew and killed William Pennington, against the lord king's peace and his crown and dignity. Immediately after the felony was committed, Richard Southwell, Robert Southwell, and the other four men in Southwell's entourage fled to the sanctuary of Westminster Abbey, where they were when the jurors made their report to the coroner.

A modern reader might be surprised by the dénouement of the inquest jury's report, the charge of felonious killing against Richard Southwell's brother Anthony, since the narrative suggests throughout that Pennington had brought his death on himself. Sixteenth-century legal readers, however, would have understood other signals (especially the absence of the word 'murder') that signalled a subsequent stage of the story: the granting of a pardon. The Coram Rege roll of the Court of King's Bench followed its copy of the indictment with the record that on 24 May 1533 , more than a year after the killing, the accused men presented to the court letters patent from the king, indicating the grant of a pardon to them, as well as the king's letters close directed to the justices indicating that they had each provided sufficient surety of future good behaviour towards the king and his whole people. Although the indictment had been vague about the kind of homicide of which they were accused, the pardon explicitly labelled Sir William Pennington's death a murder,

13 The value of a weapon used in a felony was forfeit to the king and therefore was assessed by the coroner's inquest jury. 
ironically acknowledging the full extent of the men's culpability at the same time as the penalty for the crime was remitted. The accused men thus went sine die (without day), that is, there would be no further court dates and thus no proceedings against them in this case. ${ }^{14}$

\section{The Larger Context of the Southwell-Pennington Dispute}

The narrative in the King's Bench records is a credible tale of a man in the grip of paranoia and rage, over-quick to anger, who meets his death when he intemperately insists on engaging in a sword fight despite being outnumbered. His killers are somewhat blameworthy themselves in their mistaken, but understandable, refusal to back down; the saving of their necks from the hangman's noose by the king's mercy seems just. Although the account in the records of the Court of King's Bench is convincing and plausible, other evidence bearing on the events leading to Pennington's death suggests that at least parts of this indictment were fictional. The most obvious disjunctures relate to evidence for the genesis of the quarrel, which the indictment fixes on private legal quarrels and insulting words but which other accounts link to a more politically significant issue, Anne Boleyn's sexual reputation. It is also possible that the account in the indictment more substantially misrepresented the events of that day, that Pennington was a much more innocent victim than the indictment paints him.

The indictment pays almost no attention to the larger context of the PenningtonSouthwell quarrel, an omission that is unsurprising as indictments as a rule did not deal with context but only with the immediate circumstances of the felony. Outside the legal formulae of the criminal indictment, however, the prior history of the two men and their political relationships were essential to understanding the quarrel. The indictment does not mention that both Southwell and Pennington were retainers of key members of the king's council. Southwell was in the service of Thomas Howard, duke of Norfolk, among the handful of most powerful men in the kingdom. About twenty-nine years old in 1532, Southwell may have been brought up in the Howard household alongside the duke's son, Henry Howard. ${ }^{15}$ Sir William Pennington was allied with, and related by marriage to, Charles Brandon, duke of Suffolk and the

14 TNA, KB 27/1087, rex m. 8. The letters patent granting the pardon were also recorded on the patent rolls; TNA, C 66/661, m. 5 .

15 Lehmberg, "Southwell, Sir Richard (1502/3-1564)." 
king's brother-in-law; at the time of his death, Pennington was about forty-five. ${ }^{16}$ Given the two men's connections and the proximity of the affray to the royal palace, it is not surprising that the killing caused a sensation at court. A diplomatic report written three days after the affair by the Venetian ambassador, Carlo Capello, for the Venetian Signory, reported on the rumours. ${ }^{17}$ In Capello's version, it was Southwell rather than Pennington who instigated the quarrel, and he indicates the spark for the dispute was a slur on the virtue of Anne Boleyn uttered by Pennington's patroness, the duchess of Suffolk, who was also the king's sister. For Capello, the quarrel was primarily about faction, and he identifies the main players in terms of their relationship to competing magnates.

On its own, the Venetian ambassador's repetition of gossip is no more credible indeed, one might initially suppose, less credible - than a criminal indictment presented in a court of law. On balance, however, the subsequent reaction to the killing by the king, his ministers, and the duke of Suffolk suggests that Capello's version is more reliable. The historians who have briefly discussed the murder, dependent on Capello's account as well as letters and other records now in the State Papers, have agreed with the ambassador's suggestion of factional genesis and the likelihood of an insult to Anne Boleyn as the precipitating factor. The proposed Boleyn marriage caused a major rift at court and within the king's council; Anne being the duke of Norfolk's niece, Norfolk favoured the match whereas the duke and duchess of Suffolk were implicitly (and sometimes explicitly) hostile. ${ }^{18}$ Even taking into consideration the King's Bench material, which previous historians have not studied, I think this is still the correct context in which to view the Pennington killing. The most compelling evidence supporting the allegation of an insult to Anne Boleyn as the origin of the quarrel is the reaction of Charles Brandon, the duke of Suffolk. Although in the short term, according to Capello, Suffolk was enraged by the killing of his retainer and dissuaded only with difficulty from taking revenge on Southwell, ${ }^{19}$ on sober reflection, as evidenced by a letter he himself wrote several months later, Suffolk was determined to distance himself from Pennington. Suffolk wrote to Thomas Cromwell in July 1532, intently insisting - and praying Cromwell in the strongest terms to convey to the king - that rumours of his determination to take revenge

16 Gunn, Charles Brandon, 53, 125; Foster, Pedigree of Sir Josslyn Pennington, 46, 50-51.

17 Brown, ed., CSP Venetian, 4:332.

18 Gunn, Charles Brandon, 119.

19 Brown, ed., CSP Venetian, 4:332. 
on Southwell, even that he would attack him as he stood at the high altar if need be, were utterly untrue. ${ }^{20}$ Suffolk had every reason to feel resentment towards men who, it was clear, were going to get away with having murdered his kinsman and "chief gentleman," as Capello termed him in his report. His anxious disavowal of vengeance in such circumstances can only be explained by Suffolk's own precarious position in relation to the Pennington-Southwell quarrel — his wife's, and presumably his own, implication in insulting Anne Boleyn. Suffolk's determination to leave the case alone may also have influenced the apparent decision by William Pennington's widow, Frances, not to pursue a private prosecution of the homicide. A widow could undertake an 'appeal of death,' instead of or along with a felony indictment, from which she might win damages from those responsible for her husband's death. ${ }^{21}$ Frances Pennington became Suffolk's dependant following her husband's death; she lived in his household, and her son and Pennington's heir, also named William, became part of Suffolk's retinue when he came of age. ${ }^{22}$ Thus, she may have been deferring to Suffolk's wishes in choosing not to pursue her own prosecution of her husband's death.

The aftermath of the death of Sir William Pennington unfolded in this highly fraught political situation: the simmering and potentially violent dispute between the Norfolk and Suffolk camps on the king's council, and the highly delicate matter of the reputation of the king's intended bride. It would not at all have suited the king - reported to be, unsurprisingly, greatly displeased by the $\mathrm{affair}^{23}$ - to have imputations of Anne Boleyn's unchastity introduced as an issue in the prosecution of a homicide at King's Bench. The situation required, and received, skilful handling in order to remove any discussion of insults to Anne Boleyn from official processes and records and to defuse the potentially incendiary situation between Norfolk and Suffolk. Although the identity of those managing the situation remains largely obscured, the sure hand of Thomas Cromwell, rising in the king's service in the spring of 1532, is in evidence at various points. Cromwell had several reasons to be interested in the case. Its settlement would have suited him not only as servant of the king (and

20 Charles, duke of Suffolk, to Cromwell, 20 July 1532, TNA, SP 1/70, fols. 165r-166v, calendared in Brewer et al., eds., Letters and Papers, 5:520, available at <http://www.british-history.ac.uk/ report.aspx?compid $=77489>$.

21 Baker, Oxford History, 6:512-14; Bellamy, The Criminal Trial, 35-39. There is no sign of an appeal by Frances Pennington in the King's Bench records for the year following the death (the period during which an appeal had to be launched).

22 Gunn, Charles Brandon, 125.

23 Brown, ed., CSP Venetian, 4:332. 
for his own career advancement) but also as one of Richard Southwell's personal friends, Southwell having been Cromwell's son's tutor in the 1520s and continuing to be intimate with Cromwell through the 1530 s. $^{24}$ Cromwell's task required a delicate handling of behind-the-scenes negotiations and of the official processes demanded by the king's law, calling for subtle political skills and legal strategies. What is of interest here, then, is exactly what those strategies were. If the version of the quarrel recorded in the records of King's Bench is partly, or even largely, a fiction, what shape did that fiction take?

\section{Inside and Outside King's Bench: Managing the Aftermath}

The manipulation of the case began immediately, with two events that took place at least notionally - on the day of the killing itself: first, the flight to sanctuary at Westminster and, second, the finding of the coroner's inquest jury.

Both the indictment emanating from the coroner's inquest jury and Carlo Capello's report to the Venetian Signory indicate that immediately following the killing of William Pennington, the Southwell brothers and the other co-accused sought the privilege of Westminster sanctuary. Once having been granted the privilege which involved admission of the felony, an oath before the abbot's representative, and enrolment in the sanctuary's register - a sanctuary man could not be arrested by royal officials or other authorities but had the legal right to remain unmolested within the sanctuary's boundaries. Sanctuary in the Tudor era has been portrayed, somewhat inaccurately, as an ecclesiastical encroachment on royal justice, which by the end of the first decade of Henry VIII's reign had been considerably eroded by activist judges at King's Bench. ${ }^{25}$ This view both misunderstands the integration of sanctuary privilege into the operation of common law justice in the early Tudor realm and underestimates its continued vigour even at the eve of the monastic dissolution, which brought it to an abrupt, if not complete, end. ${ }^{26}$ This case shows its relatively

24 Lehmberg, "Southwell, Sir Richard (1502/3-1564)."

25 For the standard scholarship on sanctuary, see Thornley, "Sanctuary in Medieval London" and "The Destruction of Sanctuary"; Ives, "Crime, Sanctuary, and Royal Authority"; and Baker, Oxford History, 6:540-51.

26 Revisionist accounts include Rosser, "Sanctuary and Social Negotiation"; Kaufman, "Henry VII and Sanctuary"; Helmholz, The Ius Commune; McSheffrey, "Sanctuary"; and Jordan, "A Fresh Look at Medieval Sanctuary." Margaret McGlynn's forthcoming volume in the Selden Society series will recalibrate our understanding of the relationship between the common law and sanctuary privilege; McGlynn, Common Lawyers on the Church. 
mainstream functions in Henry VIII's reign, with a few revealing twists. It was not unusual for gentlemen involved in violent quarrels ending in death to use sanctuary as a bolt-hole while friends and patrons arranged a pardon or other mitigation. Sanctuary was more secure than hiding out at large in the realm, as breaching sanctuary was sacrilege.$^{27}$ For those who could afford the expense, residence in sanctuary was also a far more comfortable option than waiting out the legal processes in a cell in the Marshalsea prison. The flight of Southwell and his fellows to the Westminster sanctuary thus fits a pattern, and the eventual pardon and dismissal of the charges was also a common outcome in similar cases. ${ }^{28}$

In other ways, however, the grant of the Westminster sanctuary's privileges to the Southwell party was somewhat unusual. Most striking is that the killing itself took place within the sanctuary precinct. ${ }^{29}$ For obvious reasons, one of the bars to the seeking of sanctuary privilege was committing the felony inside the sanctuary itself; a felon who committed a crime within a sanctuary could flee to another sanctuary and seek its privilege, but those who committed an unlawful killing in Westminster sanctuary could not, in theory, then seek Westminster's privilege. ${ }^{30}$

27 Sanctuary was occasionally breached by officials acting on behalf of the king, although such a breach could be ruled by the justices at King's Bench to be unmerited, and they might order those seized by sheriffs or their servants to be restored to the privilege of sanctuary. See, for instance, the 1521 case of Thomas Wrexham (TNA, KB 27/1040, rex m. 15) and the 1530 case of Maurice Bull and Nicholas Roo (TNA, KB 27/1075, rex m. 4), and more generally Baker, Oxford History, 6:541.

28 For a few examples dating from about the same time, see TNA, KB 27/1063, rex m. 3 (1526); KB 27/1066, rex m. 14d (1528); KB 27/1071, rex m. 1 (1529); KB 27/1075, rex m. 2d (1530); KB 27/1091, rex m. 4 (1534); and KB 27/1094, rex m. 2 (1535).

29 The indictment indicates that the killing took place on the causeway connecting the precinct and Tothill Street and clearly states that it took place within the sanctuary boundary; TNA, KB 9/520, m. 12. Capello similarly reports that the homicide took place within the sanctuary; Brown, ed., CSP Venetian, 4:332. A map of the Westminster sanctuary boundaries drawn by Marjorie Honeybourne in 1932 shows the causeway as outside the precinct boundaries, but it is unclear what her basis for this part of the boundary line is, and this case suggests that she was mistaken on that small point; Honeybourne, "Sanctuary Boundaries." Although the coroner's inquest jury's report may be prevaricating on the location of the killing as on some other aspects, it seems likely that the causeway was indeed inside the sanctuary boundary, a location which, from a legal perspective, would have been distinctly inconvenient for the Southwells and the others indicted.

30 Helmholz, The Ius Commune, 34, 51-56; Mazzinghi, Sanctuaries, 29; Kempe, Historical Notices, 146-51. Whereas a number of others were indicted for homicides inside sanctuary boundaries, in none of the other cases is there any indication of a claim of the privilege within the same sanctuary, although in one case the accused felon fled to another sanctuary. For the latter, see TNA, KB 27/1107, rex m. 4; for examples of other cases of homicide within sanctuary precincts, see KB 9/327, m. 22; KB 9/353, m. 96; KB 9/417, m. 128; KB 9/467, m. 15; KB 27/1001, rex m. 1d; KB 27/1004, rex m. 15; and KB 27/1023, rex m. 1. 
And yet the Southwells and their party did ask for sanctuary and were, moreover, granted the privilege without any sign that it was challenged. This indicates the likelihood that in the immediate aftermath of the killing some signal was sent to the abbot of Westminster or to the sanctuary's registrar that he should allow some bending of the rules to grant their request of the privilege. ${ }^{31}$ It also suggests that those who might later have contested their right to the privilege - for instance, the king's attorney, who in other cases at King's Bench raised objections to the granting of sanctuary and similar privileges ${ }^{32}$ - were instructed not to intervene. Clearly political expediency trumped legal technicalities. Notably that renowned opponent of sanctuary, Thomas Cromwell, seems to have been complicit in this employment of the privilege. ${ }^{33}$

It is not clear how long the Southwells and their fellows spent in sanctuary. The only indication of their whereabouts between their entry into sanctuary on 20 April 1532 and the conclusion of their case more than a year later on 24 May 1533 is an entry on the King's Bench Controlment Roll (administrative notes on the progress of cases through the court). This record indicates that they appeared in court in Trinity term 1532, which ran from mid June into July. ${ }^{34}$ By this time, they were apparently no longer in the sanctuary. This is suggested not only by their appearance in court, but also by the evidence of a list of those privileged at Westminster sanctuary, on which the Southwells and the others charged in the Pennington slaying do not appear. ${ }^{35}$

31 The abbot of Westminster, John Islip, was a member of the king's council and was among those working for the king's divorce in the late 1520s; both he and his successor, William Benson or Boston, elected in the spring of 1533, had excellent working relationships with the Crown. Islip may, however, have played little direct role in this particular situation as he died less than a month later. Harvey and Summerson, "Islip, John (1464-1532)"; Knighton, "Benson [name in religion Boston], William (d.1549)."

32 See, for instance, TNA, KB 27/996, rex m. 22; KB 27/1018, rex m. 11; KB 27/1075, rex m. 3; and KB 27/1111, rex m. 12.

33 A note Cromwell wrote to himself in 1536, in which he puts the "utter destruction of sanctuaries" on his agenda, is often cited as evidence for his implacable opposition, although in practice, as this case shows, his views could be more pragmatic than ideological; TNA, SP $1 / 102$, fol. $5 \mathrm{v}$, calendared in Brewer et al., eds., Letters and Papers, 10:93, available at <http://www.british-history.ac.uk/ report.aspx? compid $=75414>$.

34 TNA, KB 29/165, m. 15d.

35 TNA, SP 1/70, fol. 133. This list, with forty-nine names, may be incomplete, however, as a similar list compiled the subsequent year (TNA, SP 1/238, fols. 72-73) names ninety privileged persons, a number of whom are missing from the 1532 list despite their privilege having been granted two years or more before. 
The date of the list, 15 June 1532, coincides exactly with the day their initial pardon was granted. It is possible that even though they were not fully discharged from the felony until May 1533, the initial grant of the king's pardon was sufficient to permit their exit from the sanctuary, perhaps into the safety of the duke of Norfolk's household, until the processes at King's Bench terminated. It is also possible that they were imprisoned in the Marshalsea at this point, although the Controlment Roll does not indicate custody but only the continuation of the process from term to term until concluded in the Easter term in $1533 .{ }^{36}$

The second event that is said to have occurred on the very day of the killing was the finding of the coroner's inquest jury recorded in its report. Although dated on the day of the death, 20 April 1532, it is unlikely that the extant version was written on that day, as this version was submitted to the Court of King's Bench on 10 July 1532, two and a half months after the killing. ${ }^{37}$ There is evidence, in fact, that a previous version existed, as in the starker administrative record of the case in the King's Bench Controlment Roll, the bare facts were presented somewhat differently: it was Anthony Southwell who was named first as principal, followed by Richard and the others as accessories. ${ }^{38}$ This would, in fact, have made for a more standard indictment for homicide: it was Anthony, not Richard, who committed the slaying, and since he was the principal felon, the indictment would normally have focused on him rather than on Richard, an accessory. It can thus be inferred that the indictment we now have was written later than its purported date, and that the narrative it presents reshaped an original indictment that highlighted Anthony's role; it is possible that original indictment also included details about slurs on Anne Boleyn, which would obviously have had to be changed, too. The second question is who composed the extant coroner's report. It could have been the coroner or the jurors themselves who

36 TNA, KB 29/165, m. 15d. The record in KB 27/1087 rex m. 8 is also silent on where the accused were between the indictment and the final appearance in Easter term 1533.

37 "Per manus infranominati coronatoris die jovis proximo post $\mathrm{xv}^{\mathrm{nam}}$ sancti Johannis Baptiste isto eodem termino"; KB 9/520, m. 12d. Although few such rolls from the sixteenth century survive, we know from earlier examples, from statutory provisions concerning coroners, and from references in the King's Bench records that coroners kept their records on a roll and then were later to submit copies to the Court of King's Bench in cases not determined at gaol delivery; Hunnisett, ed., Sussex Coroners' Inquests, xiii-xx.

38 TNA, KB $29 / 165, \mathrm{~m}$. 15d. The entry in the roll also has significant amounts of text rubbed out, indicating some subsequent revisions; see <http://aalt.law.uh.edu/AALT2/H8/KB29no165/ bKB29no165dorses/IMG_0430.JPG>. 
were persuaded to establish a narrative for the events that reshaped the jurors' perception of the events..$^{39}$ Given the political imperatives surrounding the case, however, it is unlikely that the report was left to the coroner or the jurors; what is more likely is that they signed on to a report composed by others. The elaborate report suggests a careful drafting hand, possibly that of Thomas Cromwell. Cromwell was directly involved in the management of the case and, not surprisingly given his talents, he had an eye for effective rhetoric. ${ }^{40}$

Whoever wrote the indictment shaped the story it told according to the legal requirements and the generic conventions of homicide indictments submitted to English courts. The indictment borrowed some of its language and framing from homicide indictments that alleged self-defence, for instance. In a conventional indictment for murder, the victim was in God's peace and the king's when suddenly he or she was beset by the felon, who attacked with force and arms, with malice aforethought. Relatively typical was the indictment of Richard Robbesley for the death of Henry Hawes in 1529:

They [the jurors] say on their oath that the aforesaid Henry Hawes on 16 February of the said twentieth year of the aforesaid king's reign was in the dwelling house of a certain Helen Harper, widow, in the aforesaid parish of St. Botulph without Aldersgate in Aldersgate ward in London, in God's peace and the lord king's, when around seven p.m. of that day along came a certain Richard Robbesley, late of London, yeoman, otherwise called Richard Robbesley, merchant of the Staple of Calais, who feloniously as a felon of the lord king, with force and arms, that is, with knives and a dagger, against the lord king's peace, as a result of the assault and premeditated malice, attacked the aforesaid Henry. With a dagger worth $12 d$ held in his right hand, Richard Robbesley feloniously struck Henry on his back under his left shoulder, giving him with the dagger a mortal wound on his body three inches deep and more. Henry immediately died from that wound on

39 In another contemporary case (1527) where coroner's inquest jury's reports were allegedly manipulated, it was the jurors themselves who were accused of having made a misleading report, rather than the coroner or a third party; TNA, SP 1/42, fols. 126r-145r.

40 A hand identified as that of Thomas Cromwell corrected and sharpened a draft of a Chancery petition in the case cited above; TNA, SP $1 / 42$, fols. 126-128. The correcting hand is identified as Cromwell's in Brewer et al., eds., Letters and Papers, 4/2:1461, available at <http://www.britishhistory.ac.uk/report.aspx? compid $=91290>$. 
the day and year and in the parish and ward abovesaid. And thus the jurors say on their oath that the aforesaid Richard Robbesley in the manner and form abovesaid feloniously slew and murdered the aforesaid Henry Hawes, against the peace of the lord king and his crown and dignity. ${ }^{41}$

In self-defence narratives, it was the victim, filled with rage, who instigated hostilities, while the assailant was in God's peace and the king's when the victim attacked him with force and arms, as in the indictment of James a Horton for the death of Christopher Trapmell in 1516:

The jurors [...] say on their oath that the said Christopher Trapmell on Monday, 24 February, in the seventh year of the reign of King Henry VIII around nine o'clock at night at St. Martin le Grand in London, with force and arms, that is, with swords and daggers, attacked James a Horton, recently of London, yeoman, and beat him and would have killed him. James fled from the aforesaid Christopher up to a certain stall of a shop there and backed up as far as he could until there was no further he could flee. And Christopher furiously followed James up to the said stall so that James could only escape with his life from the said Christopher by taking a sword, worth $20 \mathrm{~d}$, for the salvation of his life, to defend himself, and striking Christopher on his head, and in this manner and form, as the only way to save his own life, he killed him, and not violently or with malice aforethought. ${ }^{42}$

The indictment of the Southwells resembles the self-defence narrative more closely than the standard murder indictment: at no point was Richard Southwell or any of his retinue accused of "malice," premeditated or not, while Pennington was repeatedly said to have acted with "magna malicia" and to press the conflict onwards. Southwell and his retinue did not attack with force and arms, and although Anthony Southwell's blow was felonious, he was not said to have murdered Pennington, but to have killed and slain him, pointing towards manslaughter rather than murder. ${ }^{43}$ The Southwell indictment did not explicitly argue for self-defence, however; in a standard self-defence narrative, it would have been emphasized that the accused was faced with the stark choice of his own death or defence by striking back. As in

41 TNA, KB 9/513, m. 62; KB 27/1076, rex m. 7 (my translation from the Latin original). Robbesley was ultimately acquitted as the trial jurors found that the murderer was someone else altogether.

42 TNA, KB 9/473, m. 76; KB 27/1023, rex m. 1 (my translation from the Latin original). Horton was pardoned.

43 Manslaughters were often pardoned; see Kesselring, Mercy and Authority, 103-107. 
the indictment of James a Horton, this was often dramatized by a trope of being cornered: the accused fled as far as he could from his attacker but ran up against a wall, or a hedge, or a market stall, and had no option but to turn, take out his sword or dagger (conveniently at hand), and fight. ${ }^{44}$ The Pennington killing was not framed this way. Richard Southwell did not flee from his attacker; he went out to meet him. Even if, in the final moments, Richard Southwell's life was in danger as he lay on the causeway and Pennington stood over him ready to plunge in his sword, the man who inflicted Pennington's mortal wounds, Anthony Southwell, was not personally being threatened. Anthony did not act in self-defence, but in defence of his brother's life, a significant distinction in legal terms. ${ }^{45}$ The indictment's approach towards, but ultimate refusal of, the full self-defence narrative arc was a cultural rather than a legal choice, a point to which I shall return.

Although in most ways the coroner's inquest jury's report observed legally necessary points and employed formulaic phrases, its attention seems to have been directed less at the bench than towards an extra-curial audience. An interesting aspect of this carefully crafted document is that it was not a watertight criminal indictment. It focuses on an accessory to homicide rather than the principal felon. It indicates the day on which the killing happened, but not the hour. It is far from exhaustive in identifying the accused, giving none of them aliases or indicating their alternative places of origin. These lacunae opened the door to claims of alibis or mistaken identity, that the men brought to court were not the same persons as named in the indictment; the pardon, by contrast, is meticulous, giving Richard Southwell, for instance, eight aliases.$^{46}$ The indictment is, perhaps most strikingly, vague and even

44 For other examples, see TNA, KB 9/422, m. 2; KB 27/1001, rex m. 1d; and KB 27/1107, rex m. 4. See also Green, "Societal Concepts," 673-75.

45 Green found that fourteenth-century self-defence verdicts were sometimes given in similar cases where a person slew someone in defence of his or her kin, but later fifteenth- and sixteenth-century appeals to self-defence employed a stricter definition; see Green, "Societal Concepts," 680-82; and Baker, Oxford History, 6:561.

46 The indictment refers to Southwell only as "Ricardus Southwell nuper de London armiger"; TNA, KB 9/520, m. 12. The pardon, on the other hand, was granted to "Ricardo Southwell nuper de London armigero, alias dicto Ricardo Southwell de London gentylman, alias dicto Ricardo Southwell de Rysynge in comitatu Norf' armigero, alias dicto Ricardo Southwell de Craneworthe in comitatu Norf' amigero, alias dicto Ricardo Southwell nuper de Rysynge in comitatu Norf' armigero, alias dicto Ricardo Southwell nuper de Craneworthe in comitatu Norf' armigero, alias dicto Ricardo Southwell de Norf', alias dicto Ricardo Southwell armigero consanguinio et heredi Roberti Southwell militis"; TNA, C 66/661, m. 5; and KB 27/1087, rex m. 8. 
conspicuously careless about who, beyond Anthony Southwell who dealt the mortal blow, had committed a felony. Although the value of the sword with which Richard Southwell struck William Pennington in their swordfight was assessed, as was usual when a weapon was used in a felonious homicide, his blow is not explicitly stated to be felonious, and it was not clearly identified as having contributed to Pennington's death. After stating that Anthony Southwell feloniously "slew and killed" Pennington, the report rather ambiguously continues that the others each helped and maintained one another in fleeing the scene,${ }^{47}$ without indicating explicitly that they were accessories to the killing, Anthony being the only specified felon. Normally homicide indictments are precise, even annoyingly repetitious, in connecting the felonious actions of the accused to the unlawful death, because vagueness could easily be raised as grounds for an acquittal. ${ }^{48}$

The way this indictment was used, however, indicates that the legal loopholes were not intended to provide Richard Southwell with a means of escape from the charges. Instead, they confirm that the shaping of this legal narrative had little to do with obtaining a particular result at law. The technical problems with the indictment were irrelevant - and known in advance to be so - because a deal had already been struck. The potential to challenge the indictment as insufficient in law was not realized, because it was in no one's interest, least of all Richard Southwell's, to do so. Southwell and his cohorts would not contest the charges but would play their roles in the official pageant at King's Bench, knowing that the pardon would be delivered. The justices themselves would also play the parts assigned to them, going through the motions of the process, receiving and enrolling the documents in the official record, and pronouncing the charges dismissed.

Using both legal and cultural conventions, the narrative establishes a careful balance of fault and pardonable conduct. In the indictment's narrative, Southwell is legally culpable, as an accessory, in Pennington's death but is nonetheless heroic, meting out violence in due measure in order to defend his honour and name and to contain and snuff out Pennington's uncontrolled rage. That the indictment's focus is on the world outside the court as well as, and perhaps more than, the judicial process

47 TNA, KB 9/520, m. 12; KB 27/1087, rex m. 8 (see Appendix).

48 The pardon, on the other hand, was much more precise in connecting the accused to the felony; TNA, C 66/661, m. 5; KB 27/1087, rex m. 8. For acquittals on technical errors in indictments, see Baker, Oxford History, 6:524. 
within it can also be seen in its formal aspects, including the presentation of an unusual wealth of detail and the reporting of long passages of dialogue. Some of the details are legally irrelevant, and at some points the tenor of the narrative particularly its appeal to tropes of aristocratic masculinity, honour, and violence - sits somewhat uncomfortably with the king's law.

Most striking in the indictment of the Southwells is the incompatibility of its appeal to aristocratic honour, and the employment of violence to settle insults against it, with the standard self-defence narrative. This incompatibility is shown up particularly by a comparison of the indictment of the Southwells with indictments where the jurors argued for self-defence. When a man was said to have killed in self-defence, the narrative presented a particular kind of masculine conduct. ${ }^{49}$ When faced with attack, the accused did not respond in kind, but fled, running as fast and as far as he could, with the malicious and enraged attacker in hot pursuit. He reacted with violence only when all other means of escape had been exhausted. These were, to be sure, legal requirements for the killing to be deemed self-defence, ${ }^{50}$ but they nonetheless reflect a particular model of masculine comportment. In one reading, such a man was one who responded reasonably to the irrational evil exhibited by the attacker, employing violence only as a last resort. He was a man of moderation, dignity, and discipline, an ideal, perhaps, of patriarchal masculinity. Yet, as Lyndal Roper has suggested, that ideal of manly conduct was more ambivalent than a straightforward reading of early modern conduct manuals - and legal definitions of self-defence might suggest. The exercise of physical force was fundamental to masculine honour, perhaps especially but not exclusively in aristocratic culture, at the same time as it was deeply disruptive to good governance and social order. The "psychic strength" of early modern masculinity, as Roper puts it, encompassed that tension between the control of violence and the potential for its employment. ${ }^{51}$ The question when the moment of necessity came, when the potential for violence had to turn to actuality, was a delicate one, and the moment demanded in aristocratic honour culture was sometimes different from the moment English homicide law allowed. Although the

49 As Walker points out, women were very rarely able to claim self-defence; the homicide law was, in a sense, gendered male; Walker, Crime, Gender and Social Order, 113-58.

50 Green, Verdict According to Conscience, 28-64.

51 Roper, Oedipus and the Devil, 109, 113-17, 119-20 at 119; and Kaeuper, Chivalry and Violence, esp. 129-60; Shepard, Meanings of Manhood, 127-51; Neal, The Masculine Self, esp. 156-66; and Stretton, "Misogyny and Male Honour." 
man in the self-defence narrative ultimately resorted to violence, much of the storyline's focus was on his determination to run away from a challenge rather than facing up to it. He may thus have fit the legal requirements for self-defence, but he also fit the definition of a "stark coward," to use Pennington's term.

In the indictment for the Pennington killing, Richard Southwell was emphatically not such a man. In the jurors' narrative, Southwell and Pennington modelled two other styles of masculinity, neither of which involved shrinking from violence. The distinction between Pennington's and Southwell's uses of violence allowed for more subtle shadings regarding the use of force, culpability, and justifiable conduct. Sir William Pennington represented the intemperate, raging man, whose violence had become unhinged and ultimately led to his own demise. Richard Southwell, on the other hand, was not the instigator of the quarrel, but responded when challenged, keen to ensure that no one besmirched his reputation for courage.

Southwell thus emerges from the homicide indictment as a hero, Pennington as a villain. We cannot know whether this was even a remotely fair depiction of what happened. Small dissonances both within and outside the narrative of the indictment raise doubts. Capello, the Venetian ambassador, for instance, suggests that it was Southwell who attacked Pennington rather than vice versa. He also indicates that Southwell was accompanied by twenty men, rather than the six who are named in the indictment. This scenario - Southwell besetting Pennington with a retinue that dwarfed Pennington's - would have produced quite a different narrative, as indeed it does in very sketchy form in Capello's report, with Southwell's actions cast in a much less favourable light. In fact, the indictment itself is inconsistent on the question of relative numbers in the two retinues. Although both Pennington and Southwell are said to have been accompanied by six men, at one point Pennington (foolishly) presses on to confront Southwell even as his servant warns him that "there be many more then we be." 52 The pardon - which names another Southwell servant unmentioned in the indictment - also suggests that Southwell's party was at least somewhat bigger than the indictment indicates. ${ }^{53}$

It seems likely that the particular balance struck in the indictment was the product of some negotiation, faint traces of which appear in various records. One participant in the indictment narrative, for instance, John Peryent, was not what

52 TNA, KB 27/1087, rex m. 8.

53 TNA, C 66/661, m. 5. 
he seems; although he is cast in the indictment as a neutral intermediary trying to bring peace between the parties, he was in fact closely related to the Southwells, being their stepfather..$^{54}$ Peryent may also have been more implicated in the killing than the indictment suggests; the King's Bench Controlment Rolls note that at some point in the weeks following the slaying, Peryent was arrested on suspicion of murder. ${ }^{55}$ Even more curious than the arrest itself, the entry records that the sheriffs of London arrested Peryent at the suggestion of none other than Thomas Cromwell. This attribution is hard to reconcile with the other evidence that Cromwell was working to tamp down the hostilities and that, if anything, he was working on the Southwells' behalf. My best guess for Cromwell's order of the Peryent arrest is that it had become necessary in the weeks following the death to put some pressure on Peryent - and perhaps, by extension, on the Southwells - to accept the account that the official version records. They, perhaps, wanted a full exoneration. In what may have been a compromise, Peryent was ultimately cleared altogether and the Southwells were guilty but rhetorically justified in the killing of Pennington and were to receive a pardon.

The pardon itself did not come gratis, and no doubt was another element of negotiation. ${ }^{56}$ The king unofficially levied a hefty fine on Southwell for the pardon, a note among Cromwell's memoranda recording that Southwell paid $£ 1000$ for it, ${ }^{57}$ perhaps as a quid pro quo for the tone the indictment struck. The time needed to gather the funds for the fine (which included selling manors) is likely to account for the delay of almost a year between the enrolment of the pardon on the Patent Roll in June 1532 and its presentation at King's Bench in May 1533. ${ }^{58}$

54 Nichols, The Topographer and Genealogist, 2:561.

55 "Johannes Peryent captus fuit apud villam Westm' in comitatu Midd' pro suspeccione felonie et murdri"; TNA, KB 29/165, m. 10d. One anomaly, among many, was that he was arrested in Westminster by the sheriffs of London, rather than Middlesex; the London sheriffs should have had no jurisdiction over the case or in Westminster. The case was eventually dismissed.

56 On pardons in general, and on the political manoeuvres they sometimes involved, see Kesselring, Mercy and Authority, esp. 93, 121-29.

57 TNA, SP 1/68, fols. 142-43. Other scattered documents and letters in the State Papers indicate that Southwell rendered at least one-third in cash and surrendered two manors to the king to pay the fine. TNA, SP 1/68, fols. 142-43; SP 1/71, fols. 47, 91; and BL, Cotton Vespasian C XIV 1, fol. 166. Cromwell may have lent Southwell some money to help pay the fine, as suggested by Southwell's personal debt of $£ 200$ to Cromwell recorded in September 1532; Brewer et al., eds., Letters and Papers, 5:555, available at <http://www.british-history.ac.uk/report.aspx?compid=77492>.

58 Another possible reason for delay was that the widow's time period to launch an appeal was a year and a day following the husband's death; see above, note 21 . 
If these final proceedings at King's Bench might seem to have put an end to the whole affair, the last chapter in the larger story suggests that not all issues had been resolved. In March 1534, at the next sitting of Parliament following the dismissal of the charges against Richard Southwell and his retinue, the terms of the pardon as enrolled in the Patent Roll and recorded at King's Bench were confirmed by an Act of Parliament. ${ }^{59}$ This was a very unusual move - there were only two other special pardons confirmed by statute in the reign of Henry VIII, neither very similar to this one. ${ }^{60}$ It is unclear why, in Southwell's case, it was thought necessary to ratify a relatively common type of pardon, for a homicide committed during an ostensibly private quarrel between two gentlemen. ${ }^{61}$ The use of the parliamentary pardon suggests, however, that the outcome of the case was not well received by all, and required some bolstering. That, in turn, hints that the circumstances of the death were known, at least by those who mattered, to have been quite different from the story told in the indictment, with Southwell's part more sordid and less heroic than it appears in the official records.

The report of the coroner's inquest jury on the killing of Sir William Pennington was, thus, at least partly fictional; the narrative, however, was not infinitely malleable. The composer of a legal narrative did not have as much freedom as the writer of literary fiction, most obviously because the narrative had to conform to what would credibly appear to the court to be true. Certain elements of the story told in the Southwell indictment which do not fit with the narrative logic suggest either careless story-telling or, more likely, the retention of certain plot points precisely because they were known or thought to be true. Most obvious is the identity of the principal felon. In the logic of the story told in the indictment, the killer should have been Richard Southwell, the indictment's protagonist, but instead Richard's hitherto barely mentioned younger brother Anthony emerges suddenly at the crisis point and

5925 Hen. VIII, c. 32, Statutes of the Realm, 3:489. Parliament adjourned on $30 \mathrm{March}$, and this bill went through three readings in the House of Lords on 27 March; Journal of the House of Lords, $1: 80$.

60 One was passed in the same session of Parliament and concerned accusations against the bishop of Norwich regarding the politically sensitive offence of praemunire (i.e., a legal appeal to the papal court, seen as challenging royal supremacy), while the second concerned, somewhat ironically, the duke of Suffolk and a number of his retainers, whose pardon of certain debts was ratified by statute in 1536; 25 Hen. VIII, c. 29 and 27 Hen. VIII, c. 37, Statutes of the Realm, 3:486-87, 590.

61 Lehmberg, without commenting on it further, refers to it as a "private act" for Southwell; Lehmberg, The Reformation Parliament, 189. 
strikes the mortal blow. This problem was, however, not insurmountable. In a general legal sense, it did not really matter who struck the blow, because those who fought alongside Anthony Southwell were all liable to be charged as accessories to homicide, another felony for which the normal punishment was the same as for homicide, namely, hanging. The indictment's structure reflects Richard Southwell's primary responsibility for Pennington's death in broader terms - not legally, but politically and perhaps even morally. It was Richard who was assessed the fine for the pardon (there is no sign that the others were similarly fined); he was the first named in the pardon as well as in the indictment and in the proceedings recorded on the Coram Rege roll at King's Bench; and ultimately it was his name that featured in the title of the parliamentary act confirming the pardon. ${ }^{62}$ Although it would have made for a neater narrative to have Richard rather than Anthony strike the fatal blow, this is not the path the indictment took. It seems likely that it was Anthony, rather than Richard, who killed Pennington, and that this point was maintained in the story because it was already generally known that the killer was Anthony rather than Richard.

Other parts of the story can also be corroborated. Three of the major parties to the case, for instance, can be reliably placed within Westminster Hall around that particular time in the Easter law term. Sir William Pennington, John Peryent, and John Grey were all involved in lawsuits being heard before the Court of Common Pleas with a return date during the week in which Saturday, 20 April, the day of the death, fell. ${ }^{63}$ Richard and Robert Southwell, too, could well have been at the court on that day, as they were likewise involved in ongoing suits at Common Pleas. ${ }^{64}$ One last party, uninvolved (as far as we know) in the affray itself but crucial in the unfolding response to it - Thomas Cromwell - was also involved in at least one suit with a return day during the week in question and could have been a witness to some or even all of the events. ${ }^{65}$ Thus, it seems likely that the starting point for the quarrel, in Westminster Hall, is reliable.

One of the most interesting pieces of external evidence related to the narrative which the indictment tells comes from a later portrait of Richard Southwell painted

62 "An Acte concernyng the pardon of Richard Southwell and others," 25 Hen. VIII, c. 32, Statutes of the Realm, 3:489.

63 TNA, CP 40/1072, mm. 72d, 177d, 178, 635, each with a return date of the quindene of Easter, the week starting on the second Wednesday after Easter, which fell on 17 April in 1532; Cheney, A Handbook of Dates, 67-68, 102.

64 TNA, CP 40/1072, m. 118, Atts. m. 1.

65 TNA, CP 40/1072, m. 524d. 
by Hans Holbein in 1537. In both the painting, now in the Uffizi gallery in Florence (see Fig. 2), and a preliminary sketch (see Fig. 1), now in Windsor Castle, an unmistakable scar from a long cut, as from a sword, is visible on Southwell's neck just below his chin. ${ }^{66}$ The indictment indicates that Pennington cut Southwell with his sword before Southwell himself responded: "William Pennington, persevering in his said malice, came with a sword, which he then unsheathed, and pierced Richard Southwell." ${ }^{17}$ It is interesting that Southwell, or Holbein, chose to show rather than conceal the scar, as it could easily have been hidden had Southwell sat the other way; perhaps Southwell was proud of his battle wounds. It thus seems likely that a dangerous wound to Southwell (on his neck, as the portrait shows), the striking of the mortal blow by Anthony Southwell, and the general outline of the quarrel's topography, beginning in Westminster Hall and ending on the causeway between the sanctuary precinct and Tothill Street, are more or less reliable.

The point here is not to distinguish 'what happened' from what did not, what to keep and what to discard as evidence from this document, so much as it is to understand how the document was composed and how it was read, which demands that we consider what had to be massaged or changed, and what directions these changes took. The omission of the insult to Anne Boleyn is easy to understand in the context of 1533: no doubt all involved understood that rumours about Anne Boleyn's virtue could not be acknowledged. But if the composers were in any case going to establish a fictive narrative, why keep any elements? Why not make Richard Southwell, for instance, the one who strikes the mortal blow? A lie is perhaps the more convincing the more closely it hews to the truth; or perhaps the issue was the more prosaic one that Anthony had already been named as the killer in records associated with the case. It seems unlikely, however, that the point was to pull wool over the judges' eyes: although in some cases, lies told in court served to conceal crucial facts from judicial authorities, thus allowing for a legal outcome that the real facts would not have merited, ${ }^{68}$ that does not seem to have been the point here. It seems more than

66 Rowlands, Holbein, plate 93 (catalogue, p. 143). The preliminary sketch is described in Parker, The Drawings of Hans Holbein, 46-47. An image of this drawing (with catalogue description) is available at <http://www.royalcollection.org.uk/collection/912242/sir-richard-southwell-15023-1564>. My thanks to the anonymous reader for Florilegium who pointed out the scars.

67 TNA, KB 27/1087, rex m. 8 (see Appendix).

68 One example among many is the invention of a previous marriage in order to escape a subsequent union that was actually valid but no longer desired. For such a case, see McSheffrey, "Detective Fiction." 


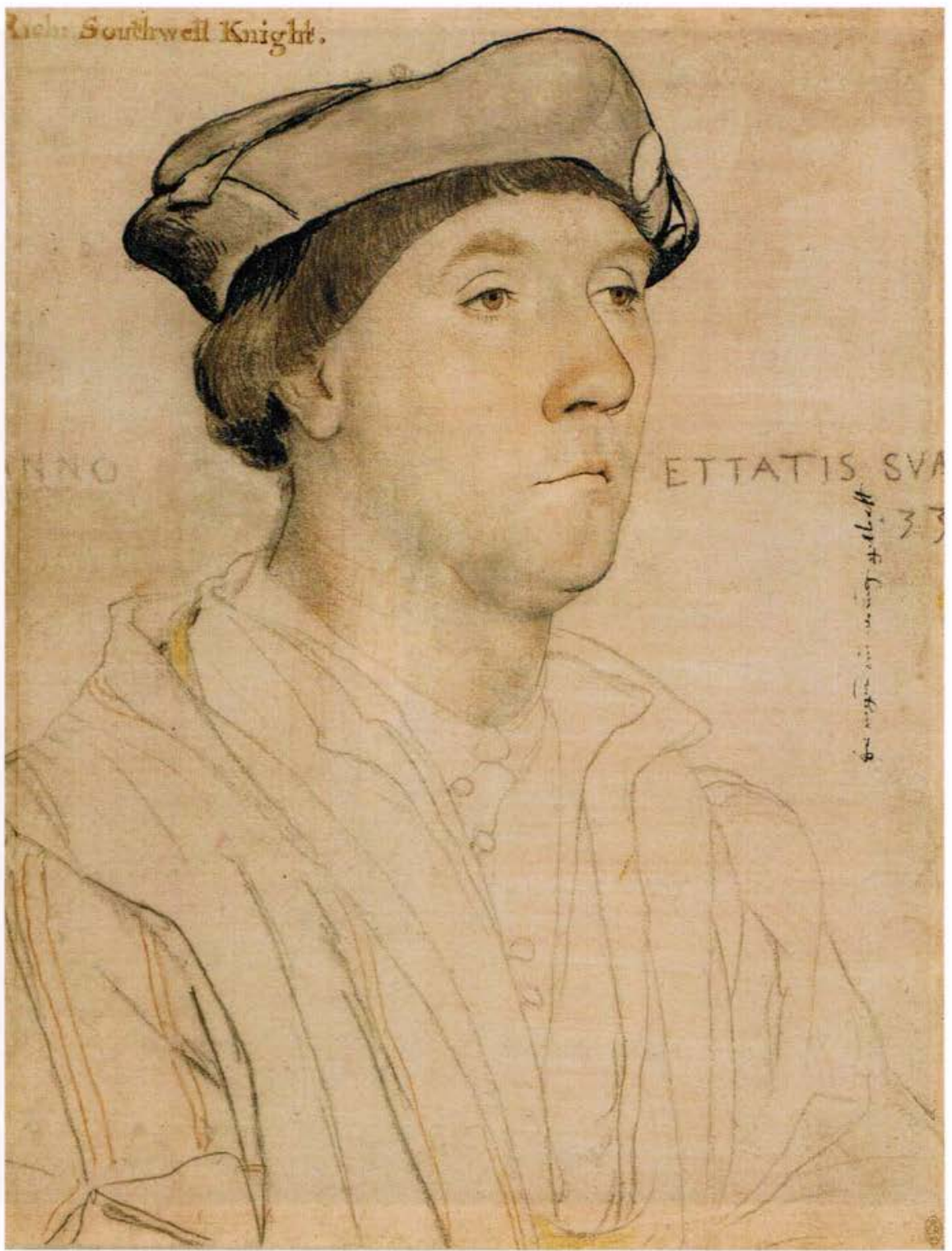

Figure 1. Hans Holbein the Younger, Sir Richard Southwell, 1536. Royal Collection Trust / @ Her Majesty Queen Elizabeth II 2013. 


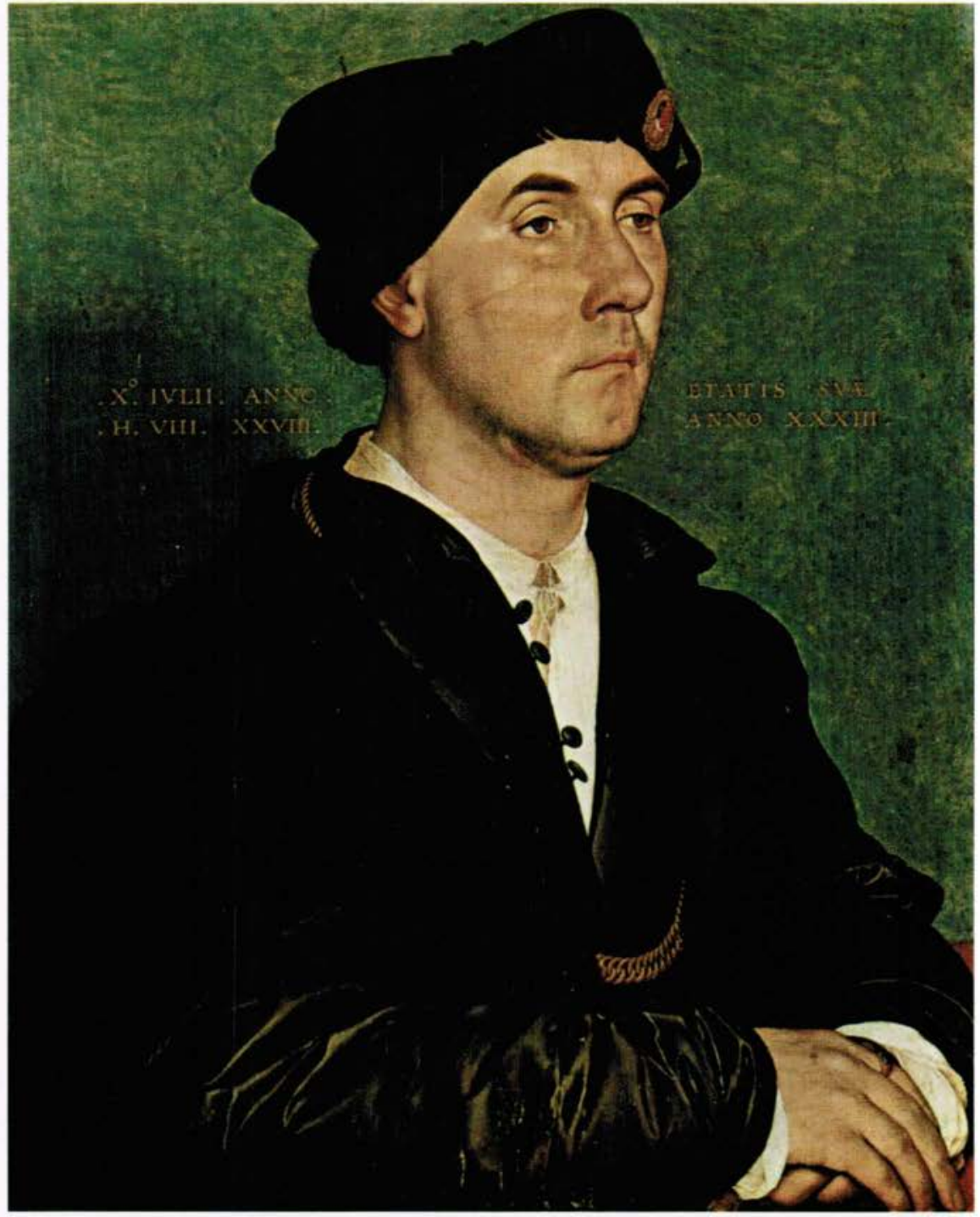

Figure 2. Hans Holbein the Younger, Sir Richard Southwell, 1536. Note the scars on his neck, his forehead, and his cheek. Uffizi Gallery, inv. 1890 n.1087. By permission of the Ministry of Culture of Italy. No further reproduction permitted. 
possible that all those involved, including the justices at King's Bench, were aware that the story being put on record was, at least in parts, an unfaithful rendition of the events. Perhaps there were limits on liberties that could be taken with what was thought to have happened that day - if the narrative might not be strictly speaking 'true,' perhaps it had to be 'truthy' enough (to use the comedian Stephen Colbert's word) to pass.

The point of the elaborate indictment and its detailed narrative, if all those who mattered had a fairly good idea that events had unfolded in a somewhat different way, remains mysterious. The best explanation is that it seemed important to Henry VIII, Cromwell, and the others involved for the official record to indicate that the king's court of law had duly addressed the unlawful killing of Sir William Pennington, without that process (and its record) re-igniting the smoldering Norfolk-Suffolk conflict and without it raising sensitive issues concerning the virtue of the king's intended bride (and, as of about January or February 1533, his wife). ${ }^{69}$ The narrative was not entirely convincing but generally coherent; the process was technically less than perfect but passably similar to other such processes; the settlement of the issues may have taken longer than originally envisaged (necessitating the act of parliament confirming the pardon), but ultimately the quarrel did not re-ignite. It was all good enough. Suffolk may have been mollified by the large fine on Southwell (and his own relief, perhaps, that his wife's insult to the future queen had not proved more costly); Southwell may have been happy with the heroic figure he cut in the indictment, not to mention keeping his neck and, as it turned out, his career.

For Southwell, the killing of Sir William Pennington took two years to clear up, but in the longer term it was to stand as a rather odd prelude to a long and successful political and administrative career. Through the following decades, Southwell served the Crown in several sensitive and important capacities, played a key role in administering the dissolution of the monasteries, sat as Member of Parliament for Norfolk, was knighted in 1540, and went on to serve as privy councillor under both Edward VI and Mary I. Although the pardon in the Pennington affair cost him a significant sum, he more than made up for it in the land grab following the monastic dissolutions, and he died a very wealthy man. He was - with a few tense moments remarkably able to withstand the vicissitudes of shifting politics during the middle

69 Henry and Anne married in secret, and thus the precise date of their marriage is unknown; see Bernard, Anne Boleyn, 66-67. On Henry VIII's particular sensitivity regarding both his sexual reputation and the reputation of his queens, see Elton, Policy and Police, 9-12. 
years of the century, a quality that speaks not so much to his heroic honour as to a rather crafty political sense and a willingness to abandon loyalty when his interests suggested. ${ }^{70} \mathrm{He}$ was thirty-three years old when Hans Holbein painted his portrait in 1536, showing a weak-chinned man who looks more a government administrator than a heroic swordsman. His brother Robert likewise went on to a distinguished legal and parliamentary career and a knighthood in 1542. Anthony, probably younger than the other two, appears to have led a less public life as a gentleman, although records show continued connections between the brothers. ${ }^{71}$

The narratives this conflict produced are revealing of the role of story-telling in legal and political contexts in sixteenth-century England. Narrative shapes our understanding of reality; we understand what happens around us through the organizing form of sequential and connected events. ${ }^{72}$ Stories are politically as well as personally powerful - skilful political actors consciously or unconsciously use narratives as rhetorical tools. Legal contexts demand that those stories fit within the evidentiary requirements established by law, ${ }^{73}$ but this does not conversely mean that the paralegal narrative elements are not also rhetorically significant inside and outside the court. If, in some cases, stories were told in legal contexts in order to conceal from legal or political authorities what really happened, the records associated with Sir William Pennington's death are likely to mask political imperatives, resulting in an 'emperor's new clothes' scenario, in which everyone knew that the story was a fiction but silently agreed to let it pass.

Concordia University

70 See Lehmberg, "Southwell, Sir Richard (1502/3-1564)."

71 Baker, "Southwell, Sir Robert (c.1506-1559)"; Brewer et al., eds., Letters and Papers, 21/1:682, available at <http://www.british-history.ac.uk/report.aspx?compid $=80865>$; and Blomefield and Parkin, An Essay Towards a Topographical History of [. . . ] Norfolk, 6:108.

72 Bruner, "The Narrative Construction of Reality," 2-5; and Brooks, "The Law as Narrative and Rhetoric," 19.

73 Gewirtz, "Narrative and Rhetoric in the Law," 5. 


\section{Appendix}

\section{The Indictment of Richard Southwell et al. for the slaying of William Pennington: Transcription and Translation}

TNA, KB 27/1087, rex $m$. 8. Punctuation has been modernized, and $u / v$ and $i / j$ have been regularized.

Middlesex. Memorandum quod Johannes Stokker Jekell coronator domini Regis nunc infra Sanctuarium beati Petri Westminster ac infra libertatem abbatis Westm' in comitatu predicto, die Jovis proximo post quindenam sancti Johannis Baptiste anno regni domini Regis nunc vicesimo quarto, per manus suas proprias deliberavit hic in Curia quandam inquisicionem coram eo captam in hec verba.

Middlesex. ${ }^{74}$ Inquisicio indentata capta apud Westminster in comitatu predicto infra Sanctuarium beati Petri Westminister ac infra libertatem abbatis Westm' in eodem comitatu vicesimo die Aprilis Anno regni Regis Henrici octavi vicesimo tercio coram Johanne Stokker Jekell coronatori domini Regis infra Sanctuarium et libertatem predictos super visum corporis Willelmi Penyngton militis ibidem mortui iacentis et felonice interfecti, per sacramentum Roberti Graunt, Johannis Lawrens, Henrici Roberdes, Philippi Lentall, Ricardi Yomans, Willelmi Jenyns, Johannis A Powell, Willelmi Cricheley, Ricardi Herberd, Thome Clowdesley, Johannis Risley, Willelmi Wharleton, Willelmi Style, Roberti Yong, Johannis Parkynson, et Oliveri Carvell. Qui dicunt super sacramentum suum quod vicesimo die Aprilis anno regni Regis predicti vicesimo tercio, ita accidit quod Ricardus Southwell nuper de London. armiger fuit ambulans sesum et gesum ${ }^{75}$ in aula vocata Westmynster Hall in predicto comitatu Midd', cui ibi venebat quidem Johannes Peryent armiger intendens pacificare certa gravamina et debata mota ex parte eiusdem Willelmi Penyngton contra predictum Ricardum Southwell. Et ut idem Johannes Peryent fuit movens dictum Ricardum Southwell pro amicabili communicacione habendi inter eos, prenominatus Willelmus Penyngton miles accessit ad predictos Johannem Peryent et Ricardum Sowthwell dicendo hec verba sequencia: "Southwell, vos intimastis Johanni Grey quod vos habuistis querelam ad ipsum. Et si non, vos dixistis quod

74 The following is the same text, with a few spelling variants, as in the King's Bench Indictment files; TNA, KB 9/520, m. 12.

75 sesum et gesum: pres. sesum for cessum 'back and forth.' 
Penyngton mentitus est." Ad quod predictus Ricardus Southwell respondebat quod ipse non fuit avisatus quod ipse sic dixisset quamvis ipse dixit quod si ipse sic dixisset ipse fuit abilis ad probandum id per bonos testes. Et super hoc predictus Willelmus Penyngton elato vultu magnaque malicia adtunc et ibidem iuravit per dei sanguinem et dixit prefato Ricardo Southwell hec verba in Anglicis sequencia: "Yf thow wyll abyde by the wordes I shall kytt thy knaves flesshe." Et predictus Ricardus Southwell tunc et ibidem respondendo dixit, "Yf thow kytt my flesshe, I shall kytt thy flesshe ageyn lyke a knave," cum quibus verbis predictus Willelmus Penyngton in magna furore et passione circa ipsius medium palpitavit pro eius armicudio ad percuciendum predictum Ricardum Southwell. Et cum idem Willelmus percipiebat quod ipse non habebat suum armicudium, idem Willelmus a prefato Ricardo Southwell recessit. Et postea infra spacium unius quarterii unius hore extunc proxime sequente predictus Willelmus Penyngton ad predictum Ricardum Southwell adtunc existentem in predicto loco vocato Westmynster Hall dispectuose dicendo hec verba sequencia, "Thow cowardly knave, if thow wyll not mete and also fight with me att Totehyll wither I wyll ymmedyatly go, I schall reporte where so ever I schall hereaftyr com that thow art the sterkest coward knave on lyve." Et super hoc predictus Willelmus Penyngton recessit versus Totehyll predictum. Et predictus Ricardus Southwell tunc existens graviter motus cum eisdem verbis se preparavit ad eundem locum appunctuatum, associatus cum quodam Roberto Southwell de London Generoso, Antonio Southwell de eadem, generoso, Matheo Fraunsham de eadem yoman, Ricardo Wood de eadem yoman, Willelmo Bofeld de eadem yoman, et David Lloyd de eadem yoman, infra spacium unius hore extunc proximo sequenti intendens ad eundum usque Totehyll predictam. Et ut idem Ricardus fuit in eundo et priusque ipse illuc veniebat, predictus Willelmus Penyngton, associatis numero sex personarum, stabat supra pontem ad finem cuiusdam calseti ${ }^{76}$ in Westminster predicta in comitatu Middlesex predicto quod iacet a monasterio sancti Petri Westminster usque Totehyll predictum in eodem comitatu. Et cum predictus Willelmus Penyngton percipiebat quod predictus Ricardus Southwell fuit super calcete predicto, idem Willelmus dixit, "Ibi venit Southwell." Et sic cum magna malicia idem Willelmus veniebat versus predictum Ricardum Southwell. Tunc Thomas Belle, serviens prefati Willelmi Penyngton, videns maliciam sui magistri ei dixit, "Sir, there be many more then we be, therfore a nother day schalbe better then nowe." Tunc dixit predictus Willelmus Penyngton, "If thow be a ferd go thy wey

76 I.e., calciato, from calciatus 'causeway.' 
orellis do as thy harte serveth the for my wey lyeth thys wey." Et sic idem Willelmus Penyngton ibat versus predictum Ricardum Southwell. Et hoc percipiens predictus Johannes Peryent et similiter periculum consideratus quod inde evenire potuit post ipsum Ricardum Southwell currendo ibat et ipsum in suis ulnis tenebat, dicendo hec verba: "Richard Southwell, for the passion of Cryste, be content. What wyll yow doo wyll yow undo yowre self and all yowres?" Ad quod idem Ricardus respondebat et hec verba sequencia locutus est, "Sir wyll ye hold me tyll I be slayne? I pray yow suffer me to be at large and stay Penyngton, and yow shall ordre me." Et cum hiis verbis supranominatus Johannes Peryent pro tanto ut in ipso fuit $[\mathrm{m} .8 d]$ inter eos ibat ad pacem custodiendum. Ad quod predictus Wilellmus Penyngton in sua dicta malicia perseverans veniebat cum quodam gladio quem ipse tunc ibidem divulgavit et ad predictum Ricardum Southwell percuciebat. Et predictus Ricardus Southwell cum quodam gladio precii quinque solidorum quem ipse in manu sua dextera adtunc et ibidem tenebat onerando et exonerando ictus dedit prefato Willelmo Penyngton adtunc et ibidem duas separales plagas, videlicet unam super faciem et aliam super brachium eiusdem Willelmi. Et predictus Willelmus senciens seipsum graviter fore vulneratus fuit graviter motus et ad predictum Ricardum Southwell percuciebat quousque idem Ricardus titubabat et cecidit fere ad quoddam fossatum ibidem adiacentem prefato calceto. Et ut idem Willelmus Penyngton existens preparatus ad percuciendum ad predictum Ricardum Southwell adtunc super terram iacentem, prenominatus Antonius Southwell percipiens periculum quod predictus Ricardus Southwell eius frater adtunc ex verisimule inesset adtunc et ibidem cum quodam gladio precii quatuorum solidorum quem idem Antonius adtunc et ibidem tenebat in manu sua dextera predictum Willelmum Penyngton super sinistram partem capitis sui adtunc et ibidem felonice percussit, et ei dedit plagam mortalem de qua quidem plaga idem Willelmus Penyngton adtunc et ibidem instanter obiit. Et sic predictus Antonius Southwell die, anno, loco, et tempore predictis super calceto predicto predictum Willelmum Penyngton felonice interfecit et necavit contra pacem dicti domini Regis coronam et dignitatem suas. Et predicti Ricardus Southwell, Robertus Southwell, Matheus Framisham, Ricardus Wood, Wilellmus Bofeld, et David Lloyd alter eorum eorundem alterum auxiliando et manutenendo fugierunt et in sanctuario Westminster in predicto comitatu Middlesex ad huc remanent et cetera. 


\section{Translation}

Middlesex. Inquest taken at Westminster in the aforesaid county within the sanctuary of St Peter's Abbey, Westminster, and within the liberty of the abbot of Westminster in the same county, 20 April in the twenty-third year of the reign of King Henry VIII [1532], before John Stokker Jekell, coroner of the lord king within the aforesaid sanctuary and liberty, over the view of the body of William Pennington, knight, lying there dead and feloniously killed, by the oath of Robert Graunt, John Lawrens, Henry Roberdes, Philip Lentall, Richard Yomans, William Jenyns, John a Powell, William Cricheley, Richard Herberd, Thomas Clowdesley, John Risley, William Wharleton, William Style, Robert Yong, John Parkynson, and Oliver Carvell. They say on their oath that on 20 April in the twenty-third year of the reign of the aforesaid king, it happened that Richard Southwell, late of London, esquire, was walking back and forth in the hall called Westminster Hall in the aforesaid county of Middlesex, when along came John Peryent, esquire, intending to pacify certain grievances and disputes moved by William Pennington against Richard Southwell. And as John Peryent was urging Richard Southwell to have an amicable conversation with him, the aforenamed William Pennington, knight, came up to John Peryent and Richard Southwell, saying the following words: "Southwell, you intimated to John Grey that you had a quarrel with him. And if you did not, you said that Pennington is a liar." Richard Southwell responded to this that no one had told him that he had ever said any such thing, but if he had, he certainly would be able to prove it by good witnesses. At this, William Pennington, with a flushed countenance and great malice, then and there swore by God's blood and spoke to Richard Southwell these words in English: "If thou will abide by the words, I shall cut thy knave's flesh!" And Richard Southwell then and there answered, "If thou cut my flesh, I shall cut thy flesh again [in return] like a knave!" At these words William Pennington, in a great fury and passion, felt around his midriff for his dagger to stab Richard Southwell, and when he realized that he did not have his dagger, he retreated. Afterwards, within the space of a quarter of an hour, William Pennington approached Richard Southwell, who was still in Westminster Hall, and disdainfully said to him, "Thou cowardly knave, if thou will not meet and also fight with me at Tothill, whither I will immediately go, I shall report wheresoever I shall hereafter come that thou art the starkest coward knave alive." With this, William Pennington went towards the aforesaid Tothill. Richard Southwell, severely angered at these words, readied himself to go to the appointed place, accompanied by a certain Robert Southwell of London, gentleman, Anthony Southwell of the same, gentleman, 
Matthew Fraunsham of the same, yeoman, Richard Wood of the same, yeoman, William Bofeld of the same, yeoman, and David Lloyd of the same, yeoman. As Richard was going there and before he reached the place, William Pennington, accompanied by six men, stood on the bridge at the end of a certain causeway in Westminster which goes from the monastery of St Peter, Westminster, to Tothill. When William Pennington saw that Richard Southwell was on the causeway, he called, "Here comes Southwell," and with great anger he advanced on Richard Southwell. Thomas Belle, servant of the aforesaid William Pennington, seeing his master's great malice, said to him, "Sir, there be many more than we be, therefore another day shall be better than now." William Pennington replied, "If thou be afraid, go away, or else do as thy heart serveth thee, for my way lieth this way." And thus William Pennington went towards Richard Southwell. Seeing this, the aforesaid John Peryent, similarly considering the danger that could come from this, went running after Richard Southwell and took him by his elbow, saying to him, "Richard Southwell, for the passion of Christ, be content. What will you do, will you undo yourself and all yours?" To this Richard answered and spoke these words: "Sir, will ye hold me till I be slain? I pray you, suffer me to be at large and stay Pennington, [if] you shall order me." And with these words, John Peryent, as much as he could, went between them to keep the peace. William Pennington, persevering in his said malice, came with a sword, which he then unsheathed, and pierced Richard Southwell. Richard Southwell, with a sword worth five shillings which he then held in his right hand, giving and parrying blows, gave William Pennington then and there two separate wounds, that is one on the face and the other on his arm. And William, sensing himself to be gravely wounded, was greatly enraged and struck at Richard Southwell until Richard staggered and almost fell into a ditch next to the causeway. And as William Pennington prepared himself to strike Richard Southwell, lying on the ground, Anthony Southwell, seeing the danger in which Richard Southwell, his brother, seemed to be, then and there feloniously struck William Pennington on the left side of his head with a sword worth four shillings. Anthony Southwell gave William Pennington a mortal wound from which he immediately died. And thus Anthony Southwell, on the day and year and at the place and time abovesaid, on the aforesaid causeway, feloniously slew and killed William Pennington, against the lord king's peace and his crown and dignity. And the aforesaid Richard Southwell, Robert Southwell, Matthew Fraunsham, Richard Wood, William Bofeld, and David Lloyd, each of them helping and maintaining the others, fled to the Westminster sanctuary in the aforesaid county of Middlesex and there they remain, etc. 


\section{Bibliography}

\section{Manuscript Sources}

Kew, Surrey, The National Archives (TNA)

C 66, Patent Rolls

CP 40, Court of Common Pleas: Plea Rolls (available through AALT, below)

KB 9, Court of King's Bench: Crown Side: Indictments Files

KB 27, Court of King's Bench: Plea and Crown Sides: Coram Rege Rolls (available through $A A L T$, below)

KB 29, Court of King's Bench: Crown Side: Controlment Rolls (available through AALT, below)

SP 1, State Papers, Henry VIII: General Series

London, British Library (BL)

Cotton Vespasian C XIV 1

Palmer, Robert. Anglo-American Legal Tradition: Documents from Medieval and Early Modern England from the National Archives in London. 2011. Available at <http://aalt.law.uh .edu/>.

\section{Published Primary Sources}

Brewer, J. S., James Gairdner, and R. H. Brodie, eds. Letters and Papers, Foreign and Domestic, of the Reign of Henry VIII. 21 vols. in 35 parts. London: Longman, Green, Longman, \& Roberts, 1862-1932. Available at <http://www.british-history.ac.uk/catalogue .asp $\mathrm{x}$ type $=3 \&$ gid $=126>$.

Brown, Rawdon Lubbock, ed. Calendar of State Papers and Manuscripts Relating to English Affairs, Existing in the Archives and Collections of Venice. Vol. 4, 1527-1533. London: HMSO, 1871.

Hunnisett, R. F., ed. Sussex Coroners' Inquests, 1485-1558. Sussex Record Society 74. Lewes, Sussex: Sussex Record Society, 1985.

Journal of the House of Lords. Vol. 1, 1509-1577. London: HMSO, 1767. Available at <http:// www.british-history.ac.uk/report.aspx?compid=31480>.

The Statutes of the Realm. 10 vols. London: G. Eyre and A. Strahan, 1810.

\section{Secondary Sources}

Baker, J. H. The Oxford History of the Laws of England. Vol. 6, 1485-1558. Oxford: Oxford Univ. Press, 2003.

__. "Southwell, Sir Robert (c.1506-1559)." Oxford Dictionary of National Biography. Oxford: Oxford Univ. Press, 2004; online ed., Jan. 2008.

Bellamy, John G. The Criminal Trial in Later Medieval England: Felony Before the Courts from Edward I to the Sixteenth Century. Toronto: Univ. of Toronto Press, 1998. 
Bernard, G. W. Anne Boleyn: Fatal Attractions. New Haven, Conn.: Yale Univ. Press, 2010. - The King's Reformation: Henry VIII and the Remaking of the English Church. New Haven, Conn.: Yale Univ. Press, 2005.

Blomefield, Francis, and Charles Parkin. An Essay Towards a Topographical History of the County of Norfolk. 11 vols. London: William Miller, 1805-1810.

Blouin, Francis X., Ir., and William G. Rosenberg, eds. Archives, Documentation, and Institutions of Social Memory: Essays from the Sawyer Seminar. Ann Arbor: Univ. of Michigan Press, 2006.

Brooks, Peter. "The Law as Narrative and Rhetoric." In Law's Stories: Narrative and Rhetoric in the Law, edited by Peter Brooks and Paul Gewirtz, 14-22. New Haven, Conn.: Yale Univ. Press, 1996.

- "Narrative Transactions - Does the Law Need a Narratology?" Yale Journal of Law and the Humanities 18 (2006): 1-28.

Bruner, Jerome. "The Narrative Construction of Reality." Critical Inquiry 18, no. 1 (1991): 1-21. Burton, Antoinette, ed. Archive Stories: Facts, Fictions, and the Writing of History. Durham, N.C.: Duke Univ. Press, 2005.

Cheney, C. R. A Handbook of Dates for Students of English History. Cambridge: Cambridge Univ. Press, 1997.

Davis, Natalie Zemon. "Les Conteurs de Montaillou." Annales: économies, sociétés, civilisations 34, no. 1 (1979): 61-73.

- Fiction in the Archives: Pardon Tales and Their Tellers in Sixteenth-Century France. Stanford: Stanford Univ. Press, 1987.

Derrida, Jacques. De la grammatologie. Paris: Editions de Minuit, 1967.

- Of Grammatology. Baltimore: Johns Hopkins Univ. Press, 1976.

Elton, G. R. Policy and Police: The Enforcement of the Reformation in the Age of Thomas Cromwell. Cambridge: Cambridge Univ. Press, 1972.

Farge, Arlette. Le goût de l'archive. Paris: Éditions du Seuil, 1989.

Foster, Joseph. Pedigree of Sir Josslyn Pennington. London: Chiswick Press, 1878.

Gaskill, Malcolm. Crime and Mentalities in Early Modern England. Cambridge: Cambridge Univ. Press, 2000.

Gewirtz, Paul. "Narrative and Rhetoric in the Law." In Law's Stories: Narrative and Rhetoric in the Law, edited by Peter Brooks and Paul Gewirtz, 2-13. New Haven, Conn.: Yale Univ. Press, 1996.

Gowing, Laura. "The Haunting of Susan Lay: Servants and Mistresses in SeventeenthCentury England." Gender \& History 14, no. 2 (2002): 183-201.

Green, Thomas A. "Societal Concepts of Criminal Liability for Homicide in Mediaeval England." Speculum 47, no. 4 (1972): 669-94.

- Verdict According to Conscience: Perspectives on the English Criminal Trial Jury 12001800. Chicago: Univ. of Chicago Press, 1985. 
Gunn, S. J. Charles Brandon, Duke of Suffolk c.1484-1545. Oxford: Basil Blackwell, 1988. Harvey, Barbara F., and Henry Summerson. "Islip, John (1464-1532)." Oxford Dictionary of National Biography. Oxford: Oxford Univ. Press, 2004; online ed., Jan. 2008.

Helmholz, R. H. The Ius Commune in England: Four Studies. Oxford: Oxford Univ. Press, 2001.

Honeybourne, Marjorie B. "The Sanctuary Boundaries and Environs of Westminster Abbey and the College of St. Martin-le-Grand." Journal of the British Archaeological Association 38 (1932): 316-34.

Ives, E. W. "Crime, Sanctuary, and Royal Authority under Henry VIII: The Exemplary Sufferings of the Savage Family." In On the Laws and Customs of England: Essays in Honor of Samuel E. Thorne, edited by Morris S. Arnold, Thomas A. Green, Sally A. Scully, and Stephen D. White, 296-320. Chapel Hill: Univ. of North Carolina Press, 1981.

Jordan, William Chester. "A Fresh Look at Medieval Sanctuary." In Law and the Illicit in Medieval Europe, edited by Ruth Mazo Karras, Joel Kaye, and E. Ann Matter, 17-32. Philadelphia: Univ. of Pennsylvania Press, 2008.

Kaeuper, Richard W. Chivalry and Violence in Medieval Europe. Oxford: Oxford Univ. Press, 1999.

Kaufman, Peter Iver. "Henry VII and Sanctuary." Church History 53, no. 4 (1984): 465-76.

Kempe, Alfred John. Historical Notices of the Collegiate Church or Royal Free Chapel and Sanctuary of St. Martin-le-Grand, London. London: Longman, Hurst, Rees, Orme, Brown, and Green, 1825.

Kesselring, K. J. Mercy and Authority in the Tudor State. Cambridge: Cambridge Univ. Press, 2003.

Knighton, C. S. "Benson [name in religion Boston], William (d.1549)." Oxford Dictionary of National Biography. Oxford: Oxford Univ. Press, 2004; online ed., Jan. 2008.

Lehmberg, Stanford E. The Reformation Parliament 1529-1536. Cambridge: Cambridge Univ. Press, 1970.

_. "Southwell, Sir Richard (1502/3-1564)." Oxford Dictionary of National Biography. Oxford: Oxford Univ. Press, 2004; online ed., Jan. 2008.

Mazzinghi, Thomas John de'. Sanctuaries. Stafford: Halden, 1887.

McGlynn, Margaret, ed. Common Lawyers on the Church: Readings from the Pre-Reformation Inns of Court. Selden Society, forthcoming.

McSheffrey, Shannon. "Detective Fiction in the Archives: Court Records and the Uses of Law in Late Medieval England." History Workshop Journal 65, no. 1 (2008): 65-78.

—. "Sanctuary and the Legal Topography of Pre-Reformation London." Law and History Review 27, no. 3 (2009): 483-514.

Neal, Derek G. The Masculine Self in Late Medieval England. Chicago: Univ. of Chicago Press, 2008.

Nichols, John Gough. The Topographer and Genealogist. Vol. 2. London: J. B. Nichols, 1853. 
Parker, K. T. The Drawings of Hans Holbein in the Collection of His Majesty the King at Windsor Castle. 2nd ed. Oxford \& London: Phaidon Press, 1945.

Partner, Nancy F. "Making Up Lost Time: Writing on the Writing of History." Speculum 61, no. 1 (1986): 90-117.

Roper, Lyndal. Oedipus and the Devil: Witchcraft, Sexuality and Religion in Early Modern Europe. London: Routledge, 1994.

Rosser, Gervase. "Sanctuary and Social Negotiation in Medieval England." In The Cloister and the World: Essays in Medieval History in Honour of Barbara Harvey, edited by John Blair and Brian Golding, 57-79. Oxford: Clarendon Press, 1996.

Rowlands, John. Holbein: The Paintings of Hans Holbein the Younger: Complete Edition. Oxford: Phaidon, 1985.

Sharpe, Kevin. Selling the Tudor Monarchy: Authority and Image in Sixteenth-Century England. New Haven, Conn.: Yale Univ. Press, 2009.

Shepard, Alexandra. Meanings of Manhood in Early Modern England. Oxford: Oxford Univ. Press, 2003.

Spiegel, Gabrielle M. The Past as Text: The Theory and Practice of Medieval Historiography. Baltimore: Johns Hopkins Univ. Press, 1997.

Steedman, Carolyn. Dust: The Archive and Cultural History. Manchester: Manchester Univ. Press, 2001; New Brunswick, N.J.: Rutgers Univ. Press, 2002.

Stein, Robert M. "Literary Criticism and the Evidence for History." In Writing Medieval History, edited by Nancy Partner, 67-87. London: Hodder Education, 2005.

Stretton, Tim. "Misogyny and Male Honour in the Life of George Puttenham, Elizabethan 'Princepleaser'." In Worth and Repute: Valuing Gender in Late Medieval and Early Modern Europe: Essays in Honour of Barbara Todd, edited by Kim Kippen and Lori Woods, 337-63. Toronto: Centre for Reformation and Renaissance Studies, 2010.

Thornley, Isobel D. "The Destruction of Sanctuary." In Tudor Studies: Presented by the Board of Studies in History in the University of London to Albert Frederick Pollard, being the Work of Twelve of his Colleagues and Pupils, edited by R. W. Seton-Watson, 182-207. London: Longmans, Green, 1924.

- "Sanctuary in Medieval London." Journal of the British Archaeological Association 38 (1932): 293-315.

Walker, Garthine. Crime, Gender and Social Order in Early Modern England. Cambridge: Cambridge Univ. Press, 2003.

Williams, Penry. The Tudor Regime. Oxford: Clarendon Press, 1979. 